\title{
Zapadalnośćc na choroby zawodowe na terenie działania Powiatowej Stacji Sanitarno-Epidemiologicznej w Bielsku-Białej
}

\author{
Małgorzata Fraś, Beata Kudłacik, Jarosław Rutkiewicz
}

Akademia Techniczno-Humanistyczna w Bielsku-Białej, Wydział Nauk o Zdrowiu

Adres do korespondencji: Małgorzata Fraś, ul. W. Broniewskiego 9, 34-120 Andrychów, tel. 606 238 563, mfras@ ath.bielsko.pl

\section{Abstract}

Incidence of occupational diseases at the territory under the authority of District Sanitary and Epidemiological Station in Bielsko-Biała

Introduction. The employees' health condition depends to a large degree on occupational risks and occurrence of harmful physical, chemical and biological factors at work. These hazards are reflected in the incidence of occupational diseases.

Purpose. Analysis of incidence of occupational diseases in 2004-2015 at the territory of the District Sanitary and Epidemiological Station in Bielsko-Biala.

Material and methodology. The source of information about occupational diseases in the city end District of Bielsko-Biała was data from individual occupational disease record sheets analysed in the Station. The analysis covered data on occupational diseases according to disease classification, gender, age and duration of exposure to harmful factors in the work environment.

Results. The noted reduction in occupational disease incidence on the territory of the Sanitary and Epidemiological Station in Bielsko-Biała during the period of 2004-2015 correlated with the general declining tendency in Poland.

In the city end District of Bielsko-Biala dominated chronic diseases of the musculoskeletal and nervous system, pneumoconiosis, hearing loss and chronic disease of speech organ prevailed, which was related to a longstanding exposure to harmful factors in the work environment.

Conclusions. In the city and District of Bielsko-Biala the declining incidence tendency of occupational diseases is maintained. Analysing morbidity of particular occupational diseases in the city and District of Bielsko-Biala shows that dominating illnesses in this group are currently skin allergies, bronchial asthma, chronic diseases of the musculoskeletal and nervous system and hearing impairment.

\section{Key words: occupational diseases, register, incidence}

Stowa kluczowe: choroby zawodowe, rejestr, zapadalność

\section{Wstepp}

Choroby zawodowe są odzwierciedleniem stanu zdrowia pracowników, który jest zależny od występowania szkodliwych czynników fizycznych, chemicznych i biologicznych w środowisku pracy.

Zgodnie z definicją ujętą $\mathrm{w}$ artykule 235 Kodeksu pracy jest to jednostka chorobowa, wymieniona w wykazie chorób zawodowych, jeżeli w wyniku oceny warun- ków pracy można stwierdzić bezspornie lub z wysokim prawdopodobieństwem, że została ona spowodowana działaniem czynników szkodliwych dla zdrowia występujących w środowisku pracy albo w związku ze sposobem wykonywania pracy [1, 2]. Wykaz chorób zawodowych stanowi załącznik do rozporządzenia Rady Ministrów z dnia 30 czerwca 2009 roku w sprawie chorób zawodowych. Rozpoznanie tej choroby u pracownika lub byłego pracownika może nastąpić w okresie jego za- 
trudnienia w narażeniu zawodowym lub po zakończeniu pracy $\mathrm{w}$ takim narażeniu, pod warunkiem wystąpienia udokumentowanych objawów choroby w okresie ustalonym w wykazie chorób zawodowych [3].

Analizując aktualną zapadalność na poszczególne choroby zawodowe, stwierdza się zmianę ich struktury. Choroby zawodowe określane jako „klasyczne”, to znaczy takie jak: zatrucia ołowiem, tlenkiem węgla, rtęcią, dwusiarczkiem węgla, pylice płuc, zespół wibracyjny, ustąpiły miejsca „nowym” patologiom charakterystycznym dla krajów rozwiniętych gospodarczo, to jest alergicznym chorobom skóry, astmie oskrzelowej, uszkodzeniu słuchu czy chorobom układów ruchu i nerwowego [4].

Choroby zawodowe są nie tylko następstwem szkodliwych czynników mierzalnych występujących w środowisku pracy, takich jak czynniki fizyczne i chemiczne, lecz mogą także wynikać ze sposobu wykonywania pracy i związanych z tym obciążeń. Przewlekłe choroby układu ruchu i układu nerwowego wywołane są przez długotrwałe obciążenia ścięgien, mięśni, kaletek maziowych, nerwów obwodowych oraz innych tkanek okołostawowych. Związane są z podnoszeniem i przenoszeniem większych ciężarów lub z nieprawidłową bądź wymuszoną pozycją ciała $[5,6]$.

Wiedza na temat charakteru chorób zawodowych pozwala na przewidywanie skutków zagrożeń dla zdrowia występujących w środowisku pracy. Wskazuje również grupy zwiększonego ryzyka u pracujących na podstawie obserwowanych zmian i zjawisk w czasie.

Profilaktyka powstawania chorób zawodowych jest istotna ze względu na wysokie koszty leczenia, które są obciążeniem nie tylko dla poszczególnych pracowników, lecz również pracodawców i społeczeństwa jako całości [7, 8].

Celem pracy była analiza sytuacji epidemiologicznej chorób zawodowych rozpoznawanych u pracowników zatrudnionych na terenie objętym działalnością Powiatowej Stacji Sanitarno-Epidemiologicznej w Bielsku-Białej w latach 2004-2015.

\section{Materiały i metody}

Źródłem informacji o chorobach zawodowych w Bielsku-Białej i powiecie bielskim były dane zawarte $\mathrm{w}$ indywidualnych kartach stwierdzeń chorób zawodowych analizowanych w Powiatowej Stacji Sanitarno-Epidemiologicznej w Bielsku-Białej. W analizie uwzględniono dane dotyczące chorób zawodowych według jednostek chorobowych, płci i wieku oraz długości trwania narażenia na czynniki szkodliwe w środowiskach pracy.

\section{Wyniki}

W okresie od 2004 do 2015 roku Państwowy Powiatowy Inspektor Sanitarny w Bielsku-Białej wydał 213 decyzji o stwierdzeniu choroby zawodowej. Wydane decyzje dotyczyły $56,3 \%(n=120)$ mężczyzn oraz $43,6 \%$ $(n=93)$ kobiet. Średnia wieku dla mężczyzn znajdowała się w przedziale 49,04-62 lata, mediana dla tej grupy wynosiła 52,67. W grupie kobiet średnia wieku wynosiła od 47,2 do 60,33 roku. Średni najkrótszy okres narażenia na czynnik chorobotwórczy $w$ analizowanym okresie dla mężczyzn wynosił 18 lat w roku 2010, a najdłuższy 30,2 roku, który odnotowano w roku 2013. Dla kobiet najkrótszy okres narażenia na czynnik chorobotwórczy w analizowanym okresie wynosił 19,75 roku w 2012 roku, a najdłuższy - 32 lata, który odnotowano w roku 2015. Kobiety miały dłuższy okres narażenia na czynnik chorobotwórczy (Tabela I).

Stwierdzone przypadki chorób zawodowych w Bielsku-Białej i powiecie bielskim w latach 2004-2015

\begin{tabular}{|l|c|c|c|c|c|c|c|c|c|}
\hline \multirow{2}{*}{ Roczniki } & \multirow{2}{*}{ Ogólem } & \multicolumn{2}{|c|}{ Mężczyźni } & \multicolumn{2}{c|}{ Kobiety } & $\begin{array}{c}\text { Wiek } \\
\text { mężczyzn }\end{array}$ & $\begin{array}{c}\text { Wiek } \\
\text { kobiet }\end{array}$ & $\begin{array}{c}\text { Lata } \\
\text { narażenia } \\
\text { mężczyzn }\end{array}$ & $\begin{array}{c}\text { Lata } \\
\text { narażenia } \\
\text { kobiet }\end{array}$ \\
\cline { 2 - 11 } & $\boldsymbol{n}$ & $\boldsymbol{n}$ & $\mathbf{n}$ & $\boldsymbol{n}$ & $\mathbf{\%}$ & $\mathbf{M}$ & $\mathbf{M}$ & M & M \\
\hline 2004 & 32 & 24 & 75,0 & 8 & 25,0 & 52,67 & 47,50 & 18,17 & 22,00 \\
\hline 2005 & 24 & 19 & 79,1 & 5 & 20,9 & 49,04 & 48,80 & 22,53 & 25,00 \\
\hline 2006 & 27 & 20 & 74,0 & 7 & 26,0 & 52,89 & 54,00 & 21,34 & 24,57 \\
\hline 2007 & 24 & 13 & 54,0 & 11 & 46,0 & 50,45 & 49,55 & 24,92 & 20,27 \\
\hline 2008 & 16 & 5 & 31,0 & 11 & 69,0 & 59,46 & 47,27 & 21,25 & 25,40 \\
\hline 2009 & 26 & 11 & 42,0 & 15 & 58,0 & 57,18 & 51,93 & 27,00 & 30,07 \\
\hline 2010 & 12 & 3 & 25,0 & 9 & 75,0 & 55,00 & 52,22 & 18,00 & 22,56 \\
\hline 2011 & 9 & 5 & 55,5 & 4 & 44,5 & 51,20 & 49,00 & 27,60 & 26,75 \\
\hline 2012 & 10 & 4 & 40,0 & 6 & 60,0 & 58,50 & 51,67 & 24,75 & 19,75 \\
\hline 2013 & 11 & 5 & 45,4 & 6 & 54,6 & 51,00 & 56,00 & 30,20 & 25,17 \\
\hline 2014 & 16 & 8 & 50,0 & 8 & 50,0 & 57,50 & 54,63 & 24,88 & 30,63 \\
\hline 2015 & 6 & 3 & 50,0 & 3 & 50,0 & 62,00 & 60,33 & 27,30 & 32,00 \\
\hline Razem & 213 & 120 & 56,3 & 93 & 43,6 & 52,67 & 51,68 & 22,37 & 24,15 \\
\hline
\end{tabular}

Tabela I. Charakterystyka osób z rozpoznaniem choroby zawodowej w Bielsku-Białej i powiecie bielskim w latach $2004-2015$. $n$-liczebność grupy, \% - procent, $M$ - średnia arytmetyczna. 


\begin{tabular}{|c|c|c|c|c|c|c|c|c|c|c|c|c|c|c|}
\hline 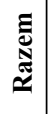 & $\stackrel{\circ}{\risingdotseq}$ & $\underset{\substack{\infty \\
m}}{\stackrel{8}{N}}$ & $\frac{+}{\frac{m}{\delta}}$ & 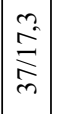 & in & 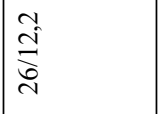 & 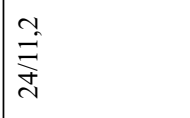 & $\begin{array}{l}0 \\
\stackrel{0}{+} \\
\stackrel{+}{\Xi}\end{array}$ & 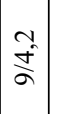 & $\begin{array}{l}\infty \\
\hat{I} \\
\text { d }\end{array}$ & $\stackrel{+}{\vec{m}}$ & $\stackrel{+}{\varrho}$ & $\stackrel{+}{\varrho}$ & \\
\hline$\stackrel{n}{\tilde{N}}$ & $\stackrel{0}{\vdots}$ & $\frac{8}{\frac{8}{6}}$ & 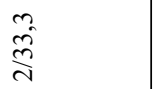 & $\mid \begin{array}{c}m \\
\stackrel{d}{d}\end{array}$ & 0 & 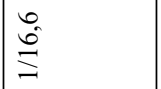 & 0 & 0 & $\mid \begin{array}{l}0 \\
\stackrel{0}{0}^{\prime}\end{array}$ & 0 & 0 & 0 & 0 & \\
\hline$\stackrel{\vec{N}}{\stackrel{N}{N}}$ & $\stackrel{\circ}{ミ}$ & $\mid \begin{array}{l}8 \\
\\
\\
-1\end{array}$ & $\begin{array}{l}: 0 \\
\frac{1}{\infty}\end{array}$ & $\frac{\vec{n}}{\frac{\hat{d}}{n}}$ & $\underbrace{1}_{\varrho}$ & 0 & 0 & 0 & 0 & 0 & 0 & 0 & 0 & $\begin{array}{l}\frac{a}{a} \\
\tilde{y} \\
\frac{a}{2}\end{array}$ \\
\hline$\stackrel{m}{\stackrel{N}{*}}$ & $\stackrel{\circ}{\vdots}$ & 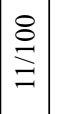 & \begin{tabular}{l}
$n$ \\
\multirow{2}{*}{} \\
$b$ \\
0
\end{tabular} & 0 & 0 & $\vec{\infty}$ & $\vec{\infty}$ & 0 & $\stackrel{\circ}{2}$ & 0 & 0 & 0 & 0 & $\begin{array}{l}8 \\
3 \\
3 \\
3 \\
0\end{array}$ \\
\hline जั & @ & $\begin{array}{c}8 \\
\stackrel{0}{0} \\
0\end{array}$ & $\begin{array}{l}\stackrel{0}{\dot{P}} \\
\frac{\partial}{\partial}\end{array}$ & 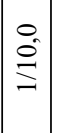 & $\stackrel{\circ}{\stackrel{8}{\Xi}}$ & 0 & $\mid \begin{array}{l}0 \\
\stackrel{\Delta}{N} \\
\text { a }\end{array}$ & 0 & 0 & $\begin{array}{l}\stackrel{0}{0} \\
\stackrel{\Xi}{=}\end{array}$ & $\stackrel{\stackrel{0}{\ominus}}{\stackrel{0}{\Xi}}$ & 0 & 0 & 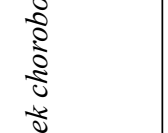 \\
\hline$\overline{\bar{\sim}}$ & $\stackrel{\circ}{\cong}$ & $\mid$\begin{tabular}{l}
8 \\
\multirow{2}{\alpha}{}
\end{tabular} & 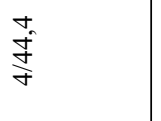 & 0 & 0 & $\vec{\Xi}$ & $\begin{array}{l}\text { İ } \\
\text { ป̂. }\end{array}$ & 0 & $\vec{\Xi}$ & o & $\vec{\Xi}$ & 0 & 0 & $\begin{array}{l}\frac{5}{5} \\
\frac{0}{300} \\
\frac{3}{3}\end{array}$ \\
\hline$\stackrel{\Xi}{\bar{N}}$ & $\stackrel{0}{\vdots}$ & $\begin{array}{c}8 \\
\stackrel{2}{2} \\
\mid\end{array}$ & $\begin{array}{l}0 \\
\stackrel{0}{0} \\
\infty\end{array}$ & 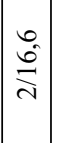 & 0 & $\begin{array}{l}0 \\
\stackrel{0}{\sim} \\
\stackrel{1}{1}\end{array}$ & 0 & 0 & $\overbrace{}^{m}$ & 0 & 0 & 0 & 0 & 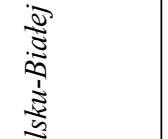 \\
\hline ڤ్̀े & $\stackrel{\circ}{\vdots}$ & 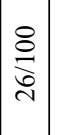 & $\begin{array}{l}\vec{b} \\
\stackrel{0}{\beth}\end{array}$ & $\left|\begin{array}{l}0 \\
\vdots \\
i\end{array}\right|$ & 0 & $\begin{array}{l}0 \\
\text { ָे } \\
b\end{array}$ & $\begin{array}{l}m \\
\hat{\sigma} \\
\frac{\gamma}{\gamma}\end{array}$ & 0 & 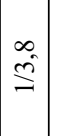 & 0 & 0 & 0 & $\stackrel{\infty}{\stackrel{\infty}{=}}$ & $\begin{array}{l}0 \\
3 \\
8 \\
8 \\
5\end{array}$ \\
\hline 嶽 & $\stackrel{\circ}{\vdots}$ & 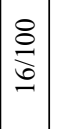 & $\begin{array}{l}\stackrel{0}{8} \\
\stackrel{n}{\infty}\end{array}$ & $\mid \begin{array}{c}1 \\
\mathscr{e} \\
=\end{array}$ & کֵ & 告 & 先 & $\mid \begin{array}{l}n \\
\hat{i} \\
\stackrel{i}{v}\end{array}$ & $\mid \begin{array}{l}n \\
\hat{i} \\
i\end{array}$ & 0 & 0 & 0 & 0 & $\frac{\sqrt{2}}{5}$ \\
\hline ڤે̀) & $\stackrel{\vdots}{\vdots}$ & 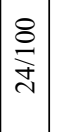 & $\begin{array}{l}0 \\
\text { in } \\
\text { in }\end{array}$ & $\mid \begin{array}{l}\vec{a} \\
\text { ì }\end{array}$ & 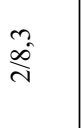 & \begin{tabular}{l}
0 \\
0 \\
\multirow{\gamma}{\gamma}{}
\end{tabular} & $\overrightarrow{\vec{I}}$ & 0 & $\vec{f}$ & $\overrightarrow{ \pm}$ & $\vec{f}$ & 0 & 0 & 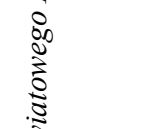 \\
\hline 怘 & $\stackrel{\circ}{\vdots}$ & 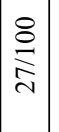 & $\begin{array}{l}\stackrel{\infty}{+} \\
\underset{f}{f}\end{array}$ & 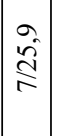 & 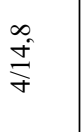 & $\vec{m}$ & $\begin{array}{l}\text { z } \\
\text { ป̂. }\end{array}$ & $\hat{s}$ & $\stackrel{s}{s}$ & $\stackrel{\vec{m}}{=}$ & 0 & 0 & 0 & $\begin{array}{l}2 \\
8 \\
8 \\
0 \\
0 \\
\vdots \\
\text { है }\end{array}$ \\
\hline ڤ̊) & 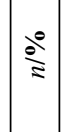 & 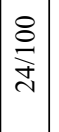 & 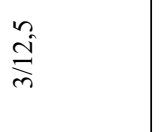 & $\left|\begin{array}{c}2 \\
\infty \\
\Delta \\
\vec{\lambda}\end{array}\right|$ & : & $\vec{I}$ & $\mid \begin{array}{l}\infty \\
\text { î } \\
\text { in }\end{array}$ & $\overrightarrow{\mathrm{I}}$ & 0 & $\overrightarrow{ \pm}$ & 0 & $\overrightarrow{\vec{I}}$ & 0 & 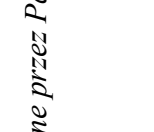 \\
\hline ثัે & $\stackrel{\circ}{ミ}$ & 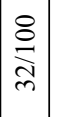 & $\begin{array}{l}\text { ڤ̂ } \\
\text { הీ }\end{array}$ & $\left|\begin{array}{c}0 \\
\frac{0}{0} \\
\frac{1}{6}\end{array}\right|$ & 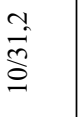 & $\begin{array}{l}0 \\
i n \\
i n\end{array}$ & $\overrightarrow{\mathrm{s}}$ & $\mid \begin{array}{c}0 \\
\frac{\infty}{6} \\
\stackrel{5}{6}\end{array}$ & 0 & 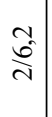 & 0 & 0 & 0 & 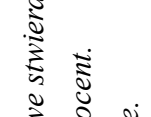 \\
\hline & 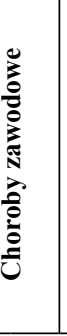 & 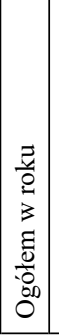 & 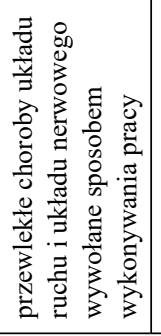 & 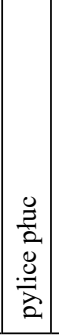 & 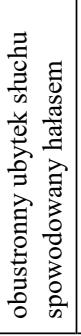 & 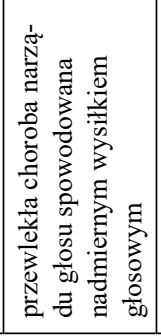 & 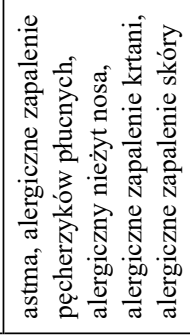 & 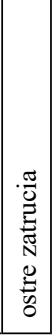 & 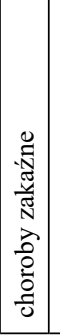 & $\begin{array}{l}\frac{3}{0} \\
0 \\
\frac{0}{N} \\
\overrightarrow{0} \\
0 \\
0 \\
0 \\
0 \\
0 \\
\end{array}$ & 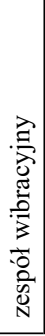 & 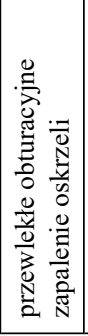 & 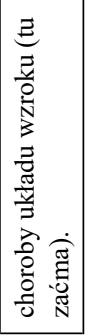 & 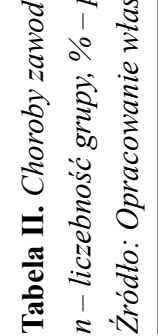 \\
\hline
\end{tabular}


dotyczyły 213 osób. Najliczniejszą grupę w tym okresie stanowiły przewlekłe choroby układów ruchu i nerwowego wywołane sposobem wykonywania pracy 67 przypadków $(31,4 \%)$; pylice płuc - 37 przypadków $(17,3 \%)$, obustronny ubytek słuchu spowodowany hałasem - 29 przypadków (13,6\%). Dużą grupę stanowiły również przewlekłe choroby narządu głosu spowodowane nadmiernym wysiłkiem głosowym - 26 (12,2\%) oraz grupa chorób alergicznych (astma, alergiczne zapalenie pęcherzyków płucnych, alergiczny nieżyt nosa, alergiczne zapalenie krtani, alergiczne zapalenie pęcherzyków płucnych, alergiczne zapalenie krtani, alergiczne zapalenie skóry) - 24 (11,2\%) (Tabela II).

$\mathrm{Na}$ podstawie analizy dokumentacji ustalono, że na terenie działania Powiatowej Stacji Sanitarno-Epidemiologicznej w Bielsku-Białej w latach 2004-2015 zarejestrowano tendencję spadkową rozpoznań chorób zawodowych z 32 zachorowaniami w 2004 do 6 w 2015 roku. Jednak należy zauważyć, że w latach 2009 i 2014 odnotowano chwilowy wzrost zachorowań (26 vs 16). Również rozkład współczynnika zapadalności na choroby zawodowe w Bielsku-Białej i powiecie bielskim uległ spadkowi - w 2004 roku wynosił 38,7, a w 2015 5,7. Jednakże w latach 2006, 2009 i 2014 odnotowano okresowe wzrosty ogólnego współczynnika zapadalności $(31,4$ vs 28,0 vs 15,2) (Tabela III).

\section{Dyskusja}

Warunki pracy zawodowej stwarzają zróżnicowane zagrożenia zdrowotne, których następstwem mogą być między innymi choroby zawodowe. Struktura patologii uznanych za zawodowe w Polsce zmienia się w ciągu lat. Do roku 1995 najwyższy odsetek był wśród schorzeń związanych z ubytkiem słuchu spowodowanym nadmiernym hałasem. W roku 1999 na pierwsze miejsce wysunęły się choroby narządu głosu [9]. Według danych odnoszących się do 2015 roku w Polsce najczęściej rejestrowanymi schorzeniami o etiologii zawodowej były choroby zakaźne lub pasożytnicze lub ich następstwa oraz pylice płuc, które stanowią odpowiednio 31,1\% i 20,2\% ogółu przypadków, a w powiecie bielskim odpowiednio $16,6 \%$ i 33,3\%. Warto podkreślić fakt systematycznego spadku liczby zatruć truciznami przemysłowymi, które w 1971 roku stanowiły 18,9\% wszystkich przypadków chorób zawodowych zarejestrowanych w Polsce [10, 11]. Natomiast w 2015 zatrucia ostre i przewlekłe lub ich następstwa stanowiły zaledwie $0,2 \%$ ogółu stwierdzonych chorób zawodowych. W Bielsku-Białej i powiecie bielskim od siedmiu lat nie notowano takich przypadków.

$\mathrm{Na}$ terenie nadzorowanym przez Państwowego Powiatowego Inspektora Sanitarnego w Bielsku-Białej, podobnie jak w całym kraju, obserwowany jest spadek bezwzględnej liczby chorób zawodowych oraz współczynników zapadalności na 100 tys. zatrudnionych (Tabela II i Tabela IV, Rycina 1).

Natomiast w województwie śląskim od 2004 do 2009 roku obserwowano spadek występowania chorób zawodowych z utrzymującą się liczbą zachorowań w przedziale od 1028 do 825 . W 2010 roku

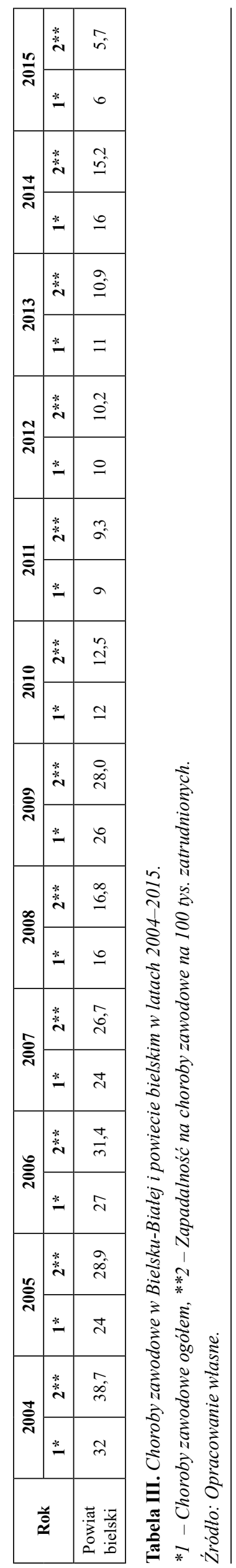




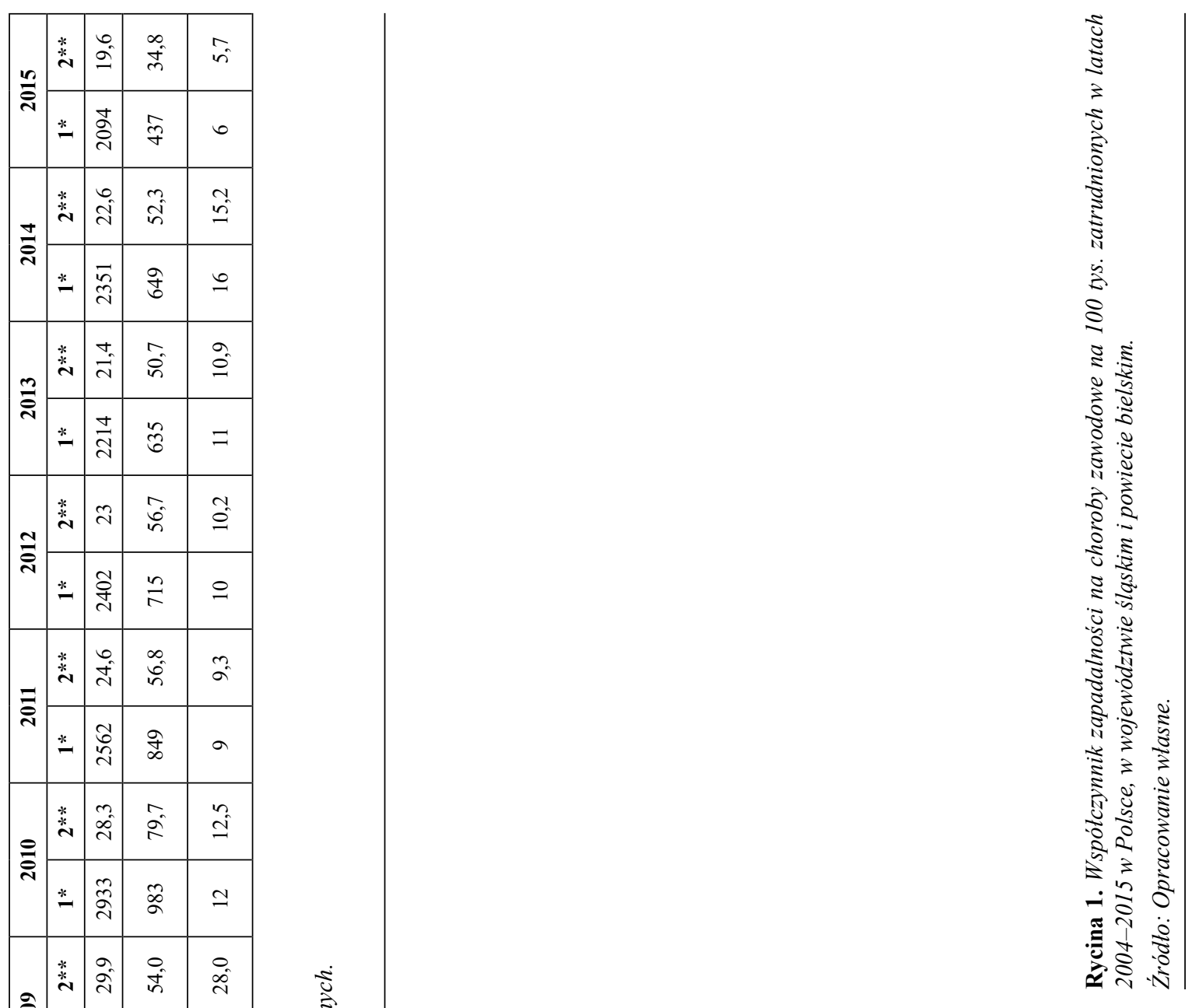

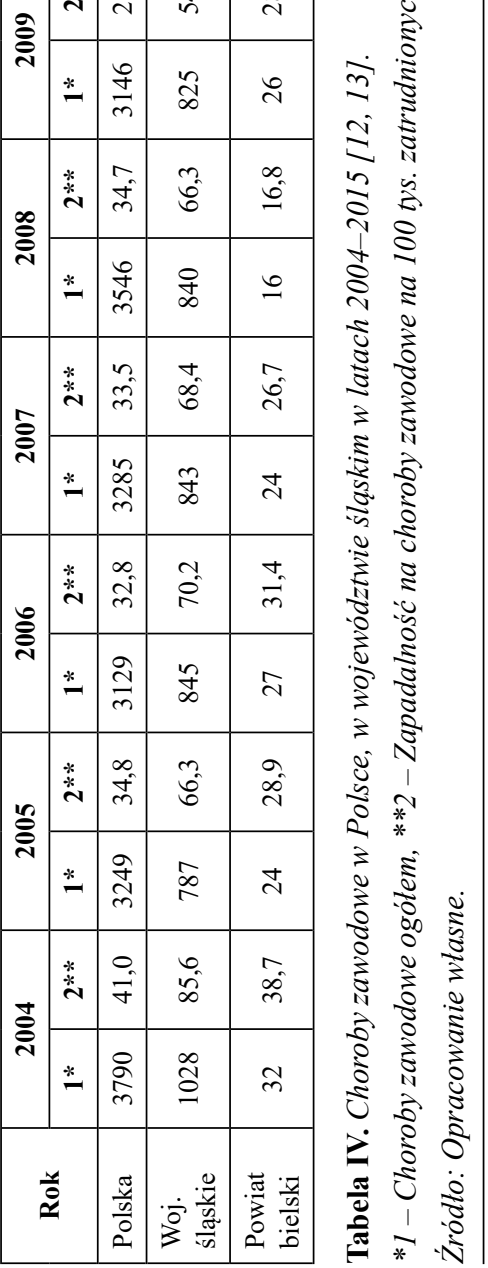

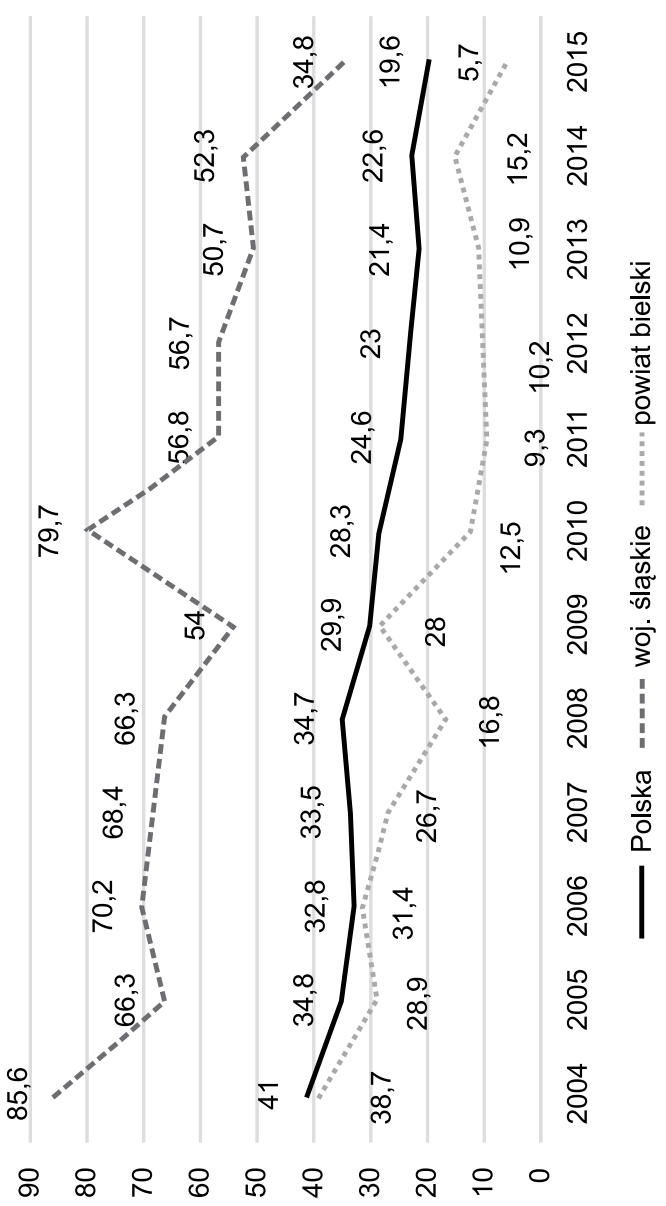


zarejestrowano 983 przypadki chorób zawodowych i od tego czasu znowu sukcesywnie odnotowywano spadek nowych rozpoznań $[12,13]$ (Tabela IV).

Współczynnik zapadalności na choroby zawodowe w Polsce (na 100 tys. zatrudnionych) w analizowanym okresie przyjmował wartość od 41,0 w 2004 do 19,6 w roku 2015. Natomiast w Bielsku-Białej i powiecie bielskim w 2004 roku wynosił 38,7, a w 2015 - 5,7. Analogicznie w województwie śląskim współczynnik zapadalności wynosił 85,6 w 2004 roku i 34,8 w 2015. Należy podkreślić, że w analizowanym okresie wartości współczynników zapadalności na choroby zawodowe w poszczególnych latach w województwie śląskim były wyższe niż w całej Polsce [10, 11] (Rycina 1, Tabela IV).

Analizując zapadalność na choroby zawodowe w latach 2004-2015 w Bielsku-Białej i powiecie bielskim, obserwuje się dominujący udział chorób układu ruchu i układu nerwowego wywołanych sposobem wykonywanej pracy, pylic płuc, przewlekłych chorób narządu głosu spowodowanych nadmiernym wysiłkiem głosowym oraz chorób o podłożu alergicznym. W Polsce natomiast w tym okresie dominowały choroby zakaźne i pasożytnicze, a następnie: pylice płuc, przewlekłe choroby narządu głosu, przewlekłe choroby obwodowego układu nerwowego i układu ruchu oraz ubytek słuchu [14-16].

W samym roku $2015 \mathrm{w}$ strukturze chorób zawodowych w Polsce odnotowano: choroby zakaźne lub pasożytnicze ( $n=652$, które stanowiły $31,1 \%)$, pylice płuc $(n=422$; $20,2 \%)$, przewlekłe choroby narządu głosu $(n=232$; $11,1 \%$ ), przewlekłe choroby obwodowego układu nerwowego $(n=186 ; 8,9 \%)$, ubytek słuchu $(n=148 ; 7,1 \%)$ oraz przewlekłe choroby układu ruchu $(n=103 ; 4,9 \%)$.

W okresie od 2004 do 2012 roku tylko w przypadku chorób układu ruchu i obwodowego układu nerwowego obserwowano tendencję wzrostową liczby rozpoznań, a dopiero w latach 2014 i 2015 ich spadek. W pozostałych przypadkach wymienionych chorób zawodowych w całym okresie od 2004 do 2015 roku odnotowano tendencję spadkową częstości ich rozpoznawania $[12,13]$ (Tabela II i Tabela V).

Specyfika zatrudnienia w poszczególnych zawodach powoduje różnice zapadalności na choroby zawodowe w zależności od płci zatrudnionych pracowników, co znalazło również potwierdzenie w badaniach własnych, z których wynika, że w Bielsku-Białej i powiecie bielskim więcej decyzji o stwierdzeniu choroby zawodowej dotyczyła mężczyzn [10].

\section{Wnioski}

1. Liczba stwierdzonych chorób zawodowych na terenie działania Powiatowej Stacji Sanitarno-Epidemiologicznej w Bielsku-Białej, w poszczególnych latach od 2004 do 2015 roku, podobnie jak w całej Polsce, sukcesywnie spada.

2. W analizowanym okresie wartości współczynników zapadalności na 100 tys. zatrudnionych w Bielsku-Białej i powiecie bielskim były zdecydowanie mniejsze niż w województwie śląskim i całej Polsce.
3. W strukturze stwierdzonych chorób zawodowych w Bielsku-Białej i powiecie bielskim na pierwszym miejsce znajdują się choroby o podłożu alergicznym, przewlekłe choroby narządu ruchu i układu nerwowego oraz uszkodzenia słuchu.

\section{Piśmiennictwo}

1. Jakubowicz J., Jakubowicz O., Żaba Cz. et al., Nowe regulacje prawne dotyczace chorób zawodowych, „Postępy Dermatologii i Alergologii” 2010; 27 (2): 122-125.

2. Ustawa z dnia 26 czerwca 1974 roku Kodeks pracy (Dz. U. 2014.15.02).

3. Rozporządzenie Rady Ministrów z dnia 30 czerwca 2009 roku w sprawie chorób zawodowych (Dz. U. z 2009 roku, Nr 105, poz. 869).

4. Hanke W., Szeszenia-Dąbrowska N., Szymczak W., Choroby zawodowe - epidemiologiczna ocena sytuacji w Polsce, „Medycyna Pracy” 2002; 53 (1): 23-28.

5. Domagała-Dobrzycka M., Zienkiewicz P., Czaja W. et al., Choroby zawodowe $w$ woj. zachodniopomorskim $w$ latach 2000-2006, „Problemy Higieny i Epidemiologii” 2009; 90 (2): 263-270.

6. Rozporządzenie Ministra Zdrowia $\mathrm{z}$ dnia 1 sierpnia 2002 roku w sprawie sposobu dokumentowania chorób zawodowych i skutków tych chorób (Dz. U. 2002, Nr 132, poz. 1121).

7. Rydlewska-Liszkowska I., Koszty chorób zawodowych $i$ wypadków przy pracy w Polsce, ,Medycyna Pracy: 2006; 57 (4): 317-324.

8. Rynowska-Wiśniewska J., Choroba zawodowa a niezdolność do pracy. Zasady orzekania, „Medycyna Ogólna i Nauki o Zdrowiu" 2014; 20 (2): 160-165.

9. Wilczyńska U., Szeszenia-Dąbrowska N., Sobała W., Drożdż D., Choroby zawodowe stwierdzone w Polsce w 2010 r., „Medycyna Pracy” 2011; 62 (4): 347-357.

10. Szeszenia-Dąbrowska N., Wilczyńska U., Occupational diseases among workers employed in various branches of the national economy. Choroby zawodowe wśród pracujacych w różnych gatęziach gospodarki narodowej, „Medycyna Pracy" 2013; 64 (2): 161-174.

11. Świątkowska B., Najczęściej stwierdzane patologie w Polsce i metody zapobiegania im, „Medycyna Pracy” 2010; 61 (6): 661-669.

12. Centralny rejestr chorób zawodowych. Dane o zapadalności; http://www.imp.lodz.pl/ (dostęp: 12.10.2016).

13. Wilczyńska U., Sobała W., Szeszenia-Dąbrowska N., Choroby zawodowe stwierdzone w Polsce w 2012 r., ,Medycyna Pracy" 2013; 64 (3): 317-326.

14. Szeszenia-Dąbrowska N., Wilczyńska U., Sobała W., Choroby zawodowe w Polsce w 2013 r. i ich czynniki przyczynowe, ,Medycyna Pracy” 2014; 65 (4): 463-472.

15. Szeszenia-Dąbrowska N., Wilczyńska U., Choroby zawodowe w Polsce w 2014 r., „Medycyna Pracy” 2016; 67 (3): 327-335.

16. Madej B., Bartuś R., Bem S., Epidemiologia chorób zawodowych $w$ Tarnowie i powiecie tarnowskim $w$ latach 1994-2003, „Przegląd Lekarski” 2006; 63 (7): 49-52. 


\begin{tabular}{|c|c|c|c|c|c|c|c|c|}
\hline \multicolumn{2}{|r|}{ Choroby zawodowe } & $\begin{array}{l}2004 \\
n / \%\end{array}$ & $\begin{array}{l}2006 \\
n / \%\end{array}$ & $\begin{array}{l}2008 \\
n / \%\end{array}$ & $\begin{array}{l}2010 \\
n / \%\end{array}$ & $\begin{array}{l}2012 \\
n / \%\end{array}$ & $\begin{array}{l}2014 \\
n / \%\end{array}$ & $\begin{array}{l}2015 \\
n / \%\end{array}$ \\
\hline \multicolumn{2}{|r|}{ Ogólem } & $3790 / 100$ & $3126 / 100$ & $3545 / 100$ & $2933 / 100$ & $2401 / 100$ & $2351 / 100$ & 2094/100 \\
\hline 1. & Zatrucia ostre albo przewlekłe lub ich następstwa & $92 / 2,4$ & $53 / 1,7$ & $26 / 0,7$ & $14 / 0,4$ & $9 / 0,3$ & $5 / 0,2$ & $4 / 0,2$ \\
\hline 2. & Gorączka metaliczna & $3 / 0,1$ & $3 / 0,1$ & 0 & $2 / 0,0$ & $1 / 0,0$ & $1 / 0,0$ & 0 \\
\hline 3. & Pylice płuc & $754 / 19,9$ & $667 / 21,3$ & $697 / 19,6$ & $790 / 26,9$ & $570 / 23,7$ & $610 / 25,9$ & $422 / 20,2$ \\
\hline 4. & $\begin{array}{l}\text { Choroby opłucnej lub osierdzia wywołane pyłem } \\
\text { azbestu }\end{array}$ & $130 / 3,4$ & $32 / 1,0$ & $40 / 1,1$ & $36 / 1,2$ & $34 / 1,4$ & $34 / 1,4$ & $54 / 2,6$ \\
\hline 5. & Przewlekłe obturacyjne zapalenie oskrzeli & $20 / 0,5$ & $18 / 0,6$ & $11 / 0,3$ & $16 / 0,5$ & $13 / 0,5$ & $11 / 0,4$ & $7 / 0,3$ \\
\hline 6. & Astma oskrzelowa & $122 / 3,2$ & $86 / 2,8$ & $89 / 2,5$ & $44 / 1,5$ & $52 / 2,1$ & $53 / 2,2$ & $47 / 2,3$ \\
\hline 7. & $\begin{array}{l}\text { Zewnątrzpochodne alergiczne zapalenie pęche- } \\
\text { rzyków płucnych }\end{array}$ & $11 / 0,3$ & $16 / 0,5$ & $15 / 0,4$ & $8 / 0,2$ & $13 / 0,5$ & $23 / 0,9$ & $19 / 0,9$ \\
\hline 8. & Ostre uogólnione reakcje alergiczne & $1 / 0,0$ & $1 / 0,0$ & 0 & $1 / 0,0$ & 0 & $2 / 0,0$ & $4 / 0,2$ \\
\hline 9. & Choroby płuc wywołane pyłem metali twardych & 0 & $1 / 0,0$ & $3 / 0,0$ & $2 / 0,0$ & $1 / 0,0$ & 0 & $1 / 0,0$ \\
\hline 10. & Alergiczny nieżyt nosa & $86 / 2,3$ & $50 / 1,6$ & $48 / 1,3$ & $36 / 1,2$ & $28 / 1,1$ & $29 / 1,2$ & $27 / 1,3$ \\
\hline 11. & $\begin{array}{l}\text { Zapalenie obrzękowe krtani o podłożu alergicz- } \\
\text { nym }\end{array}$ & $5 / 0,1$ & 0 & 0 & 0 & 0 & 0 & 0 \\
\hline 12. & Przedziurawienie przegrody nosa & $2 / 0,1$ & $1 / 0,0$ & $4 / 0,1$ & $1 / 0,0$ & $3 / 0,1$ & $1 / 0,0$ & $1 / 0,0$ \\
\hline 13. & Przewlekłe choroby narządu głosu & $881 / 23,2$ & $762 / 24,4$ & $809 / 22,8$ & $321 / 10,9$ & $202 / 8,4$ & $268 / 11,3$ & $232 / 11,1$ \\
\hline 14. & $\begin{array}{l}\text { Choroby wywołane działaniem promieniowania } \\
\text { jonizującego }\end{array}$ & $11 / 0,3$ & $22 / 0,7$ & $16 / 0,4$ & $1 / 0,0$ & 0 & 0 & $1 / 0,0$ \\
\hline 15. & Nowotwory złośliwe & $114 / 3,0$ & $104 / 3,3$ & $85 / 2,4$ & $100 / 3,4$ & $61 / 2,5$ & $80 / 3,4$ & $68 / 3,3$ \\
\hline 16. & Choroby skóry & $181 / 4,8$ & $128 / 4,1$ & $125 / 3,5$ & $110 / 3,7$ & $72 / 2,9$ & $93 / 3,9$ & $79 / 3,8$ \\
\hline 17. & Przewlekłe choroby układu ruchu & $93 / 2,5$ & $85 / 2,7$ & $120 / 3,3$ & $131 / 4,4$ & $118 / 4,9$ & $98 / 4,1$ & $103 / 4,9$ \\
\hline 18. & $\begin{array}{l}\text { Przewlekłe choroby obwodowego układu nerwo- } \\
\text { wego }\end{array}$ & $84 / 2,2$ & $108 / 3,5$ & $160 / 4,5$ & $194 / 6,6$ & $204 / 8,4$ & $167 / 7,1$ & $186 / 8,9$ \\
\hline 19. & Ubytek słuchu & $506 / 13,3$ & $295 / 9,4$ & $240 / 6,7$ & $331 / 11,2$ & $218 / 9,0$ & $169 / 7,1$ & $148 / 7,1$ \\
\hline 20. & Zespół wibracyjny & $125 / 3,3$ & $80 / 2,6$ & $84 / 2,3$ & $58 / 1,9$ & $81 / 3,3$ & $37 / 1,5$ & $28 / 1,3$ \\
\hline 21. & $\begin{array}{l}\text { Choroby wywołane pracą w warunkach podwyż- } \\
\text { szonego ciśnienia atmosferycznego }\end{array}$ & 0 & $1 / 0,0$ & 0 & $1 / 0,0$ & 0 & 0 & 0 \\
\hline 22. & $\begin{array}{l}\text { Choroby wywołane działaniem wysokich albo } \\
\text { niskich temperatur otoczenia }\end{array}$ & $2 / 0,1$ & 0 & $1 / 0,0$ & 0 & $2 / 0,0$ & 0 & 0 \\
\hline 23. & Choroby układu wzrokowego & $26 / 0,7$ & $10 / 0,3$ & $16 / 0,4$ & $7 / 0,2$ & $14 / 0,5$ & $10 / 0,4$ & $11 / 0,5$ \\
\hline 24. & $\begin{array}{l}\text { Choroby zakaźne lub pasożytnicze albo ich } \\
\text { następstwa }\end{array}$ & $541 / 14,3$ & $603 / 19,3$ & $956 / 26,9$ & $729 / 24,0$ & $705 / 29,3$ & $660 / 28$ & $652 / 31,1$ \\
\hline
\end{tabular}

Tabela V. Choroby zawodowe w Polsce w wybranych latach wedlug jednostek chorobowych [12, 13].

$n$-liczebność grupy, \%-procent.

Źródto: Opracowanie własne. 